\title{
South African energy shift will prove difficult
}

Tuesday, December 4, 2018

A new energy framework has increased focus on renewables, but also natural gas

Parliament's energy committee on November 27 finalised its comments on the Integrated Resource Plan (IRP) 2018, insisting that coal and nuclear energy should remain part of the energy mix. A new energy blueprint faced significant delays under former President Jacob Zuma (2009-18) after his unsuccessful push for a controversial expansion of nuclear capacity. However, the updated IRP from President Cyril Ramaphosa's administration focuses on renewables, as well as a large increase in natural gas.

\section{What next}

The push towards renewables and natural gas puts South Africa in line with emerging international trends. However, the substantial commitment to additional natural gas capacity will be more contentious than the push for renewables, and difficult to achieve amid uncertainties over regional supply and domestic infrastructure. The shift away from coal will prompt trade union opposition given likely job losses, which could hamper the reform efforts of Ramaphosa following his likely 2019 reelection.

\section{Subsidiary Impacts}

- The IRP's commitment to gas could renew public concern over potential shale gas production in the semi-desert Karoo.

- The focus on private-sector providers in the IRP may partially dampen investor unease over potential corruption.

- The government's move away from coal could prompt pushback from the industry's black economic empowerment (BEE) lobbies.

- Ramaphosa's administration will face public pressure to clarify its plans on how it will ensure future importation of gas and hydropower.

\section{Analysis}

In the latter years of his administration, Zuma pushed to increase nuclear energy capacity by 9.6 gigawatts, with Russia's Rosatom the preferred bidder for proposed new facilities (see SOUTH AFRICA: Nuclear plan appears a costly luxury - December 8, 2016).

Estimated to cost in excess of 100 billion dollars, the planned expansion prompted sizable domestic opposition and warnings from rating agencies over fears the proposals could bankrupt the state.

During this period, an updated version of the government's IRP regularly stalled, while state-owned power utility Eskom became a prime site of 'state capture' (corruption) and poor management -leading to rating agency downgrades by both Standard and Poor's and Moody's in 2017 (see SOUTH AFRICA: Eskom overhaul - May 29, 2018).

However, an April 2017 court ruling scuppered Zuma's nuclear plans. After Zuma's ouster by Ramaphosa in February 2018, new Minister of Energy Jeff Radebe hastened the completion of the updated IRP.

\section{IRP breakdown}

The proposed supply mix in electricity generation to 2030 includes (PDF):

- a steep reduction in the reliance on coal to 34,000 megawatts or $46 \%$ of total installed capacity; 
- a major increase in wind and solar photovoltaic (PV) power to 11,442 megawatts (15\%) and 7,968 megawatts $(10 \%)$ respectively;

- an increase in natural gas to 11,930 megawatts (16\%);

- an increase in hydropower to 4,696 megawatts (6\%); and

- maintenance of nuclear energy's installed capacity of 1,860 megawatts $(2.5 \%)$.

The commitment to gas is the most surprising and controversial aspect of the draft, considering its insignificant role in supply previously, questions about where best to source it from, a lack of supporting infrastructure and the impact on long-term carbon emissions targets.

As a signatory to the Paris Agreement on climate change, South Africa will need greater reductions in fossil fuel usage (including gas) than those envisioned in the IRP to meet its very modest Nationally Determined Contributions.

Interestingly, the IRP noted that domestic electricity demand was down $30 \%$ on previous estimates for 2010-16. The decrease in overall electricity demand is driven by stagnating economic growth, including mining output, rather than a reduction in overall energy intensity.

\section{$30 \%$ \\ Reduced domestic electricity demand between 2010 and 2016}

While reduced projected demand provides the government with additional breathing space in effecting the transition from coal to gas and renewables, the shift is complicated by a poorly performing economy and an urgent need to increase growth rates.

\section{Coal shift?}

Crucially, the IRP envisages a major reduction in the state's reliance on coal-powered energy generation.

South Africa's current 42,000 megawatts of installed coal capacity across 19 plants, with a further 6,000 megawatts of capacity currently under construction, produces $88 \%$ of its electricity supply and constitutes the world's seventh largest coal plant fleet.

While coal will remain a core part of the energy mix at $46 \%$, its role will decline substantially.

The decline of coal in favour of renewables and gas is not that surprising, mirroring international projections for electricity generation by fuel type. However, whether such a sharp reduction is realistic is questionable given that new coal-fired plants at Medupi and Kusile are expected to add 9,600 megawatts of new capacity by 2022.

As well as resulting in several 'stranded' power stations, the proposed shift will prompt sizable domestic opposition, particularly from trade unions and workers in the coal industry (and their dependents) given probable job losses.

To mitigate such effects, Radebe has stated that there will be a "just transition" for those involved in the sector, although there is little detail thus far. The ANC-aligned Congress of South African Trade Unions (COSATU) has already called for the IRP to be overhauled, amid fears over the inadequate re-skilling of workers.

\section{Wind and solar push}

The expansion of wind and solar power will be delivered through the Renewable Energy Independent Power Producer Procurement (REIPPP) programme. This push will be driven by the private sector, effectively keeping the state at a distance. 
Some 27 REIPPP projects were procured in 2015, but repeatedly delayed under Zuma's administration. The government expects 56 billion rand ( 4.7 billion dollars) in new investment by 2021 and the creation of over 60,000 jobs.

\section{Congo's political stability could determine future renewable energy supply}

Meeting the planned increase in hydropower imports will meanwhile rest on the conclusion of a treaty with the Democratic Republic of the Congo (DRC) on the Grand Inga Hydroelectric Power Project (see CONGO-KINSHASA: Grand Inga project may face pitfalls - November 9, 2018).

However, this project's future is highly uncertain given DRC's persistent political instability, related infrastructural and environmental challenges, as well as uncertainties over project financing. The Grand Inga project has already been delayed for decades.

\section{Gas gamble}

The future of gas in the electricity supply mix is less clear than that of coal and renewables. The largescale commitment to gas in the updated IRP came as a surprise, with significant implications for domestic energy security, environmental targets and international relations.

South Africa currently lacks sizable gas infrastructure. The main options for adding gas capacity are liquefied natural gas imports via Coega in the Eastern Cape and/or Richards Bay in KwaZulu-Natal province.

\section{South Africa does not have sizable gas infrastructure}

Other options are pipeline imports from Mozambique and domestic shale gas production.

There are substantial risks in long-term investments in pipeline infrastructure to bring gas from Mozambique given renewed concerns about corruption, the country's ongoing debt crisis and instability in the northern Cabo Delgado province where Mozambqiue's offshore gas deposits are located (see MOZAMBIQUE: Insecurity will weigh on post-poll outlook - November 2, 2018).

In that context, short-term contracts for LNG imports are likely to be a safer option.

Separately, prospects for shale gas exploration in the Karoo have recently diminished, in part due to significantly reduced estimates of exploitable deposits, but also due to consistent (and effective) domestic environmental opposition.

\section{Outlook}

South Africa's energy policy is less politicised under Ramaphosa but remains contested. The abandonment of major new nuclear facilities and Eskom's reduced role will mitigate concerns regarding corruption and mismanagement of public finances and state-owned enterprises.

In the short-to-medium term, the IRP's successful implementation will bring increasing labour tensions in the coal sector, a rebalancing of electricity supply in favour of private-sector supply and continued concerns about South Africa's ability to meet its climate action commitments. 